\title{
Rumah Adat Kampung Pulo Cangkuang Kabupaten Garut sebagai Konsep Hunian Masa Kini
}

\author{
Nani Sriwardani, Savitri \\ Program Studi Kriya Seni, Fakultas Seni Rupa dan Desain \\ Institut Seni Budaya Indonesia Bandung \\ Jalan Buah Batu, No.212 Bandung 40265 \\ Email: nsriwardani@ymail.com
}

\begin{abstract}
The traditional house of Kampung Pulo could be categorized as a dwelling or a house for a family. Referring to its inhabitants consisting of 4-5 people in one house, as well as space that suit with the need its inhabitants. This research aims to assess the characteristic of the form of traditional house of Kampung Pulo, that is expected to be a basic concept of a contemporary dwelling. Methods used to analyze is descriptive with a qualitative approach. Data collection techniques employ interview, observation, and documentation. The data that is described, refer to various references,. The results are the prominent characteristic of the house forms in Kampung Pulo based on the proportion, material, meanings, and function. The continuity of this research is to be applied in design recommendations for housing planning, so that it could enrich a dwelling without lost its local elements.
\end{abstract}

Keywords: Characteristic, a traditional house, Kampung Pulo, a traditional design, an alternative modern house

\begin{abstract}
ABSTRAK
Rumah adat dari Kampung Pulo dapat dikategorikan sebagai suatu hunian atau rumah tinggal sebuah keluarga. Hal ini dikarenakan di dalam satu rumah adat hanya terdiri dari satu kepala keluarga yang anggotanya berjumlah $4-5$ orang, serta luas yang sesuai kebutuhan dan aktivitas penghuninya. Bahasan ini bertujuan untuk mengkaji karakteristik bentuk rumah adat Kampung Pulo, diharapkan dapat menjadi dasar dalam memenuhi konsep hunian masa kini. Metode yang digunakan deskriptif dengan pendekatan kualitatif, yaitu studi rumah adat Kampung Pulo, berupa wawancara, observasi, dan dokumentasi. Data dideskripsikan mengacu dari berbagai referensi, dan diolah untuk dianalisis. Hasilnya ditemukan keunggulan karakteristik bentuk rumah Kampung Pulo yaitu berdasarkan proporsi, material, makna dan fungsi. Keberlanjutan penelitian ini dapat diterapkan dalam suatu rekomendasi desain atau kebijakan untuk perancangan rumah sehingga memperkaya bangunan hunian tanpa kehilangan unsur-unsur lokal.
\end{abstract}

Kata kunci: Karakteristik, rumah adat, Kampung Pulo, desain tradisional, alternatif rumah modern 


\section{PENDAHULUAN}

Rumah merupakan salah satu bagian dari kebutuhan pokok manusia. Rumah menurut Kementrian Pekerjaan Umum adalah bangunan yang berfungsi sebagai tempat tinggal atau hunian dan sarana pembinaan keluarga (http://sni.litbang.pu.go.id, diakses pada 18 Agustus 2019).

Saat ini, selain keluarga baru, tawaran hunian sederhana juga sudah menyasar pada generasi muda yang memiliki penghasilan. Kebutuhan pokok akan papan ini juga diwujudkan dalam suatu acara reality show di salah satu TV swasta dengan mengusung acara bedah atau renovasi rumah. Acara tersebut memperlihatkan bagaimana kehidupan keluarga kecil yang umumnya terdiri dari 4-5 orang beraktifitas dalam rumah bilik yang terbuat dari bambu yang kondisinya tidak layak dengan bentuk rumahnya yang hampir hancur. Program bedah rumah juga diberikan melalui Kementrian Pekerjaan Umum dan Perumahan Rakyat (PUPR), yang bertujuan mengurangi jumlah tidak layak huni (https://tirto. id/ddsd, diakses pada 18 Agustus 2019).

Berbagai tawaran dan bedah rumah saat ini umumnya dengan membangunkan rumah dengan kondisi fisik berupa bangunan modern dan luas bangunan sesuai dengan acuan standar nasional dan kriteria layak huni yang telah ditentukan oleh pemerintah (pu.go.id). Material bangunan berdasarkan standar tersebut adalah genteng, pintu, lantai dan dinding pra-cetak (kompas.com, diakses pada 18 Agustus 2019). Kelebihan material tersebut adalah mudah didapat, pengerjaannya yang cepat, dan jangka waktu perawatan yang cukup lama. Dengan demikian, material alami dan bentuk rumah dengan unsur lokal sudah mulai tergeserkan dengan bentuk dan material modern.

Berdasarkan ukuran, menurut Suryo (2007: 121) menyebutkan bahwa luas maksimal rumah sederhana dapat mencapai
38,7 m2. Acuan analisis itu juga dilihat dari SNI yang berlaku. Asumsi tersebut juga berdasarkan pada pertimbangan bahwa penghuni rumah terdiri dari 4 orang. Hal tersebut di atas memberikan gambaran bagaimana rumah atau hunian sederhana tetap menjadi kebutuhan hingga saat ini. Berbagai standarisasi telah dibuat guna dapat menciptakan rumah masal sesuai permintaan.

Rumah adat tradisional sebagai suatu hunian tetap bertahan sampai saat ini, dan dikategorikan bagian dari cagar budaya. Hal ini bertujuan agar pengetahuan budaya bangsa ini tetap terjaga. Tetap bertahannya rumah tradisional ini dikarenakan teknik dalam membangun bangunan tersebut. Salah satunya adalah dalam pemilihan material yang bersumber dari alam dan kekuatan bangunan yang mampu bertahan oleh berbagai cuaca, waktu, dan bahkan oleh gempa.

Salah satunya adalah rumah adat di Kampung Pulo yang masih bertahan dengan bentuk tradisional dan material yang berasal dari alam. Kampung Pulo memiliki aturan yang menjadi acuan dalam melangsungkan kehidupan sebagai satu kesatuan kampung maupun hunian. Sebagai suatu pemukiman, Kampung Pulo memiliki aturan jumlah penduduk, yaitu 23 orang yang terdiri dari 6 kepala keluarga, dengan 6 rumah. Artinya, setiap rumah dihuni oleh 3-4 orang. Pemukiman Kampung Pulo ini dapat dikatakan sebagai pemukiman keluarga, dikarenakan hanya boleh diisi oleh keturunan perempuan tertua dari Eyang Embah Dalem Arif Muhammad, pendiri kampung Pulo.

Rumah di Kampung Pulo tidak hanya sebagai tempat berteduh, namun di dalamnya juga berfungsi sebagai pembinaan keluarga, pewarisan budaya melalui berbagai pelaksanaan ritual adat, mengembangkan nilai-nilai budaya, dan sebagainya. Rumah adat Kampung Pulo sama halnya seperti 
rumah tradisional Sunda lainnya, berbentuk panggung dengan bahan bangunan utama dari kayu dan bambu. Salah satu yang membedakannya adalah dari pola ruangnya, terutama terletak pada jumlah ruang, tata ruang, dan luas ruang. Selain itu, rumah di Kampung Pulo ini dapat dikatakan sebagai rumah sehat, yaitu bentuk dasar rumah persegi panjang tempat jamban terpisah dengan rumah utama. Selain itu, material rumah yang alami ini menjadikan rumah memiliki sirkulasi udara yang sangat baik. Tatanan antara satu rumah dengan rumah lainnya memiliki jarak sehingga memungkinkan di setiap sisi bangunan memiliki jendela. Tatanan, bentuk dan pemilihan material tersebut memiliki makna dan maksud tertentu yang berfungsi sebagai sebuah rumah layak huni dan hunian sebuah keluarga.

Tujuan penelitian ini untuk menggali potensi, karakteristik. dan bentuk rumah adat Kampung Pulo sebagai suatu hunian atau rumah tinggal keluarga. Karakteristik tersebut dapat menjadi suatu konsep dalam merencanakan, merancang, dan menciptakan rumah keluarga layak huni. Diharapkan unsur-unsur lokal dari karakteristik Kampung Pulo dapat tetap hadir di hunian masa kini. Metode penelitian dilakukan dengan deskriptif melalui pendekatan kualitatif, yaitu melihat langsung kondisi lingkungan pemukiman Kampung Pulo yang dikhususkan pada rumah adat. Selanjutnya, dilakukan pendeskripsian, pengolahan dan analisa setiap hasil pengamatan, observasi, wawancara dan berbagai acuan literatur. Hasil dari penelitian ini untuk memberi kontribusi data berupa acuan dan informasi terhadap para pengamat, peneliti dan para perancang dalam menelaah potensial bangunan tradisional sehingga dapat diterapkan atau menjadi bagian konsep dalam desain.

\section{METODE}

Penelitian ini menggunakan metode deskriptif dengan pendekatan kualitatif. Tahapan awal adalah dengan melakukan survey pertama melalui pengamatan langsung di lapangan, bertujuan untuk memahami keadaan lingkungan sekitar kampung Pulo yang berlokasikan di Desa Cangkuang Kabupaten Garut. Survey awal meliputi kunjungan ke kantor Desa Cangkuang, bertujuan untuk mendapatkan data profil dan data statis Desa Cangkuang. Di dalamnya, termasuk keberadaan Kampung Adat Pulo dilihat juga dari sistem kepercayaan, mata pencarian, pendidikan dan sebagainya. Survey awal juga mengunjungi Kampung Pulo yang berada di pulau tengah danau, yang keberadaannya juga terdapat situs Candi Cangkuang dan makam keramat. Kegiatan tersebut didata dengan dokumentasi, pencatatan, dan wawancara.

Selanjutnya, menyusun strategi untuk menjawab rumusan masalah dari latar belakang sebelumnya, yaitu mencari berbagai data literatur dari buku, referensi dan penelitian terdahulu yang membahas keberadaan Kampung Pulo, dan teori mengenai konsep arsitektur Sunda. Melakukan survey lanjutan dengan mempersiapkan perangkat dokumentasi, pengukuran, rekaman, dan catatan. Target survey lanjutan adalah menemui pengurus cagar budaya dan pemangku adat (kuncen) sebagai target utama untuk mendapatkan data wawancara, dokumentasi setiap detail bagian rumah adat dan keseluruhan lingkungan pemukiman kampung adat, serta pengukuran untuk mendapatkan data fisik bangunan.

Hasil data survey lanjutan tersebut diolah menjadi gambar kerja, sketsa dan mendeskripsikan data wawancara serta pengamatan di lapangan. Hasil data survey selanjutnya diolah dan dianalisa bersama dengan data literatur yang telah dikumpulkan, guna menjawab pertanyaan penelitian. Pengolahan data secara berurut dilihat dari 
analisa fisik dan literatur Kampung Adat Pulo sebagai suatu kawasan pemukiman, selanjutnya menganalisa rumah adat sebagai satuan hunian. Jika terdapat enam rumah di kawasan tersebut maka dipilih rumah yang masih memiliki bentuk yang asli. Analisa tersebut bertujuan untuk menemukan karakteristik rumah adat Kampung Pulo. Cakupan analisa berdasarkan fisik bangunan seperti struktur, bentuk, material, ruang beserta ukurannya, dan sirkulasi udara rumah adat kampung Pulo. Dibalik karakteristik tersebut dianalisa untuk dilihat lebih jauh mengenai makna dan maksud dari bentuk-bentuk tersebut. Temuan karakteristik dan maknanya dari rumah adat kampung Pulo ini nantinya dapat menjadi konsep dalam perencanaan dan perancangan sebuah hunian.

\section{HASIL DAN PEMBAHASAN}

Kampung Pulo berada di Desa Cangkuang, Kecamatan Leles, Kabupaten Garut Provinsi Jawa Barat. Lebih khusus lagi, ia berada di pulau suatu danau, yang keberadaannya juga terdapat Candi Cangkuang dan makam keramat, serta museum situs. Zaki (wawancara, 16 April 2019) dari museum situs memberikan paparan rangkaian asal usul Kampung Pulo dan Candi Cangkuang. Paparannya menjelaskan keberadaaan Kampung Pulo ini dibangun oleh Eyang Embah Dalem Arif Muhammad pada abad ke-17 yang saat kedatangannya ke daerah tersebut sebagai Panglima Perang Kerajaan Mataram Islam dan beliau juga berperan dalam menyebarkan agama Islam. Saat ini, Desa Cangkuang masyarakatnya beragama Islam. Hal ini berdasarkan data dari kepala desa berupa monografi desa Cangkuang 2018. Selain itu, menurut pemangku adat/kuncen Kampung Pulo Tatang Sanjaya (wawancara, 24 Juni 2019), bahwa keturunan Eyang Embah Dalem Arif Muhammad haruslah belajar serta keluar untuk mengajarkan ajaran Is-

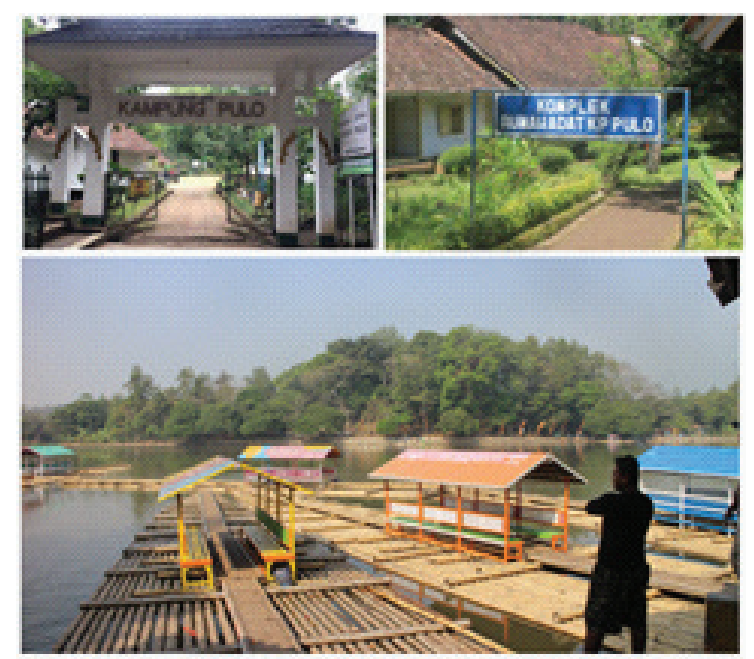

Gambar 1. Gerbang dan akses menuju cagar wisata budaya kampung adat Pulo

(Sumber: Sriwardani, 2019)

lam. Walaupun terdapat candi di lingkungan desa Cangkuang, namun penduduk setempat saat ini beragama Islam. Menurut Sanjaya, nama Cangkuang berasal dari pohon Cangkuang yang ada di dalam hutan keramat. Sedangkan, penamaan kampung Pulo dikarenakan keberadaannya wilayah sejenis pulau yang dikelilingi oleh air.

Untuk menuju lokasi ini dapat menggunakan rakit dari bambu (seperti pada gambar 1) atau dengan memilih jalan memutar. Kampung Pulo sendiri telah menjadi cagar budaya dan wisata budaya yang dikelola oleh dinas pariwisata, sehingga disediakan lahan parkir, serta fasilitas transport rakit berbayar menuju ke area wisata dan museum budaya yang menyimpan manuskrip dan berbagai data mengenai situs tersebut. Oleh karenanya, dikenakan biaya tiket masuk untuk mengunjungi wisata ini. Berbagai penjual suvenir dan jajanan juga diberi ruang untuk berjualan. Para penjual merupakan warga setempat dan beberapa keluarga dari masyarakat Kampung Adat Pulo.

\section{Kampung Adat Pulo}

Kampung Pulo terdiri dari 6 kepala keluarga dengan jumlah penduduk 23 orang, dan maksimal jumlah penduduknya tidak boleh lebih dari 26 orang. Terdapat 6 


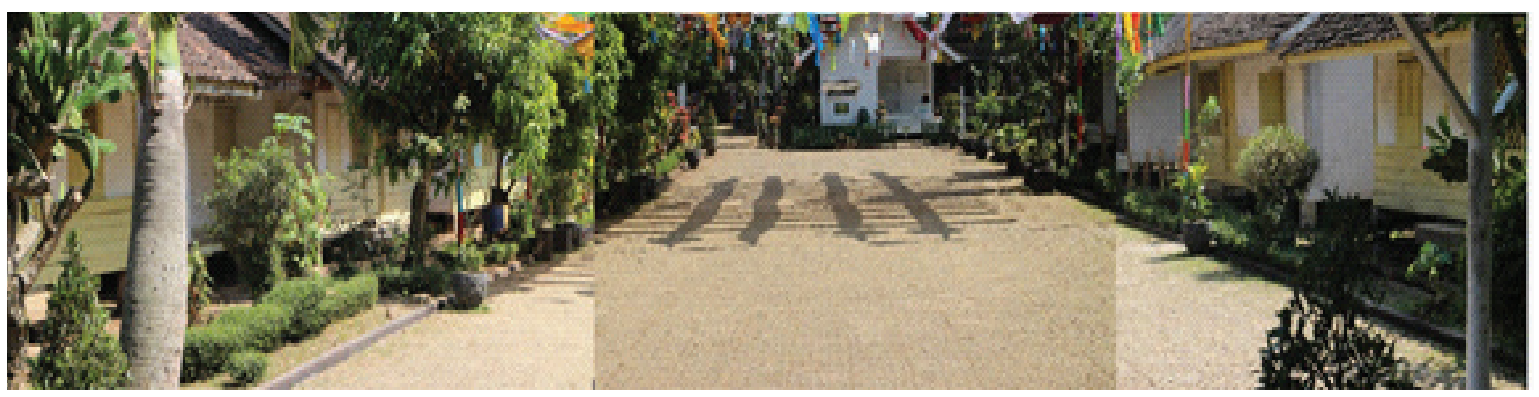

Gambar 2. Komplek Rumah Adat Kampung Pulo

(Sumber: Sriwardani, 2019)

rumah utama untuk masing-masing kepala keluarga dan 1 musola. Menurut kuncen Tatang Sanjaya (wawancara, 24 Juni 2019), dalam satu rumah diharuskan terisi oleh satu kepala keluarga saja dengan anggota keluarga yang dapat diisi oleh 4-5 orang. Pemangku adat (kuncen) menekankan bahwa tidak boleh ada dua kepala keluarga di dalam satu rumah. Jika anak sudah menikah maka maksimal dalam waktu 2 minggu ia harus keluar dari rumah. Hal ini sesuai dengan ajaran Eyang Embah Dalem Arif Muhammad, yaitu bahwa keluarga baru harus keluar mencari ilmu/belajar dan mengajarkan agama Islam. Penerus dari rumah yang ada di area kampung adat diambil dari keturunan perempuan. Sebagaimana dijelaskan oleh kuncen, bahwa 6 rumah dan satu musola merupakan gambaran dari keturunan Eyang Embah Dalem Arif Muhammad yaitu, 6 anak perempuan digambarkan sebagai rumah dan 1 anak laki berupa musola.

Keberadaan rumah adat Kampung Pulo seperti umumnya rumah tradisional lainnya yang ada di Indonesia. Gustami dalam Harissman (2019: 44) mengatakan bahwa rumah sebagai tempat berteduh, tempat tinggal, serta tempat berinteraksi antarkeluarga. Rumah juga memiliki konsep menghormati alam dan manusia serta hubungannya dengan Tuhan secara vertikal. Rumah Adat Kampung Pulo merupakan tempat interaksi dan pembelajaran bagi generasi selanjutnya. Upacara adat yang dilaksanakan di dalam rumah mengajak anak-anak, sehingga anak dapat melihat dan belajar. Kuncen juga menceritakan bagaimana saat lebaran, selesai salat id silaturahmi dilakukan di dalam rumah dan berkumpul bersama juga dilakukan di rumah. Jika lebaran kurban, maka kurban penyembelihan hewan dilakukan di luar area Kampung Adat Pulo.

Penerus yang mengisi rumah adat Kampung Pulo haruslah dari garis perempuan keturunan Eyang Embah Dalem Arif Muhammad, dengan kuncen tetaplah dipimpin oleh laki-laki, yakni suami dari perempuan keturunan Eyang Embah Dalem Arif Muhammad yang juga sebagai kepala keluarga. Kepala keluarga Kampung Pulo umumnya memiliki pekerjaan sebagai petani/peladang dan mereka mengolah lahan mereka sendiri. Kebutuhan rumah tangga terutama didapat dari hasil berkebun yang mereka olah sendiri. Seperti halnya Tatang Sanjaya, yang merupakan generasi ke-7 dari Eyang Prabu, ia hidup dengan bercocok tanam. Selain itu, terbuka juga mata pencarian lain, yaitu sebagai pedagang dan juga pegawai negeri. Masyarakat Kampung Pulo juga masih melaksanakan berbagai ritual terutama yang dilakukan pada bulan Mulud atau Rabiul Awal. Beberapa ritual tersebut adalah pada tanggal 1 Mulud yaitu syukuran menyambut bulan Mulud, $12 \mathrm{Mu}$ lud sebagai syukuran besar Mauludan yang malam harinya dilakukan kegiatan memandikan barang pusaka, 13-14 Mulud sebagai 
tengah bulan, dan 30 Mulud sebagai tanda habisnya bulan Mulud. Selain itu, terdapat juga syukuran hasil panen dan berbagai ritual lainnya. Keseluruhan aktivitas tersebut diadakan di lingkungan komplek rumah adat, baik itu di lapangan maupun di rumah bagian tepas (teras/serambi muka). Ada beberapa ritual yang hanya boleh dilakukan oleh keluarga inti atau kuncen saja, namun ada juga beberapa ri-tual yang diramaikan dan biasanya diha-diri oleh warga sekitar Kampung Pulo dan juga wisatawan.

Menurut data di lapangan serta penjelasan dari berbagai narasumber (Zaki Munawar \& Tatang Sanjaya, wawancara tanggal 24 Juni 2019) dan Saringendyanti (2008: 20-22), menjelaskan adanya hukum adat atau larangan adat yang mesti ditaati, yaitu:

1. Larangan bekerja dan berziarah pada hari Rabu. Hal ini karena hari Rabu merupakan hari pilihan untuk mempelajari dan memperdalam pengetahuan agama. Seluruh anggota masyarakat dilarang bekerja, serta diharuskan berziarah ke makam Embah Dalem Arief Muhammad. Ini juga berlaku pagi para peziarah ataupun wisatawan.

2. Larangan menambah dan mengurangi jumlah rumah. Seperti saat ini, rumah berjumlah enam dan satu musola, yang merupakan gambaran dari jumlah anak perempuan Eyang Embah Dalem Arif Muhammad. Penerus yang menempati rumah adat haruslah keturunan dan anak perempuan tertua masing-masing keluarga berupa keluarga batih, yakni satuan kekerabatan/satu keluarga yang terdiri dari ayah, ibu dan anak-anaknya.

3. Larangan memelihara hewan peliharaan berkaki empat kecuali kucing. Hal ini bertujuan untuk menjaga kesucian dan kebersihan desa adat Kampung Pulo dari gangguan dan kotoran hewan peliharaan berkaki empat selain kucing. Pengecualian terhadap kucing berkaitan dengan kepercayaan bahwa hewan tersebut merupakan peliharaan kesayangan Nabi Muhammad saw.

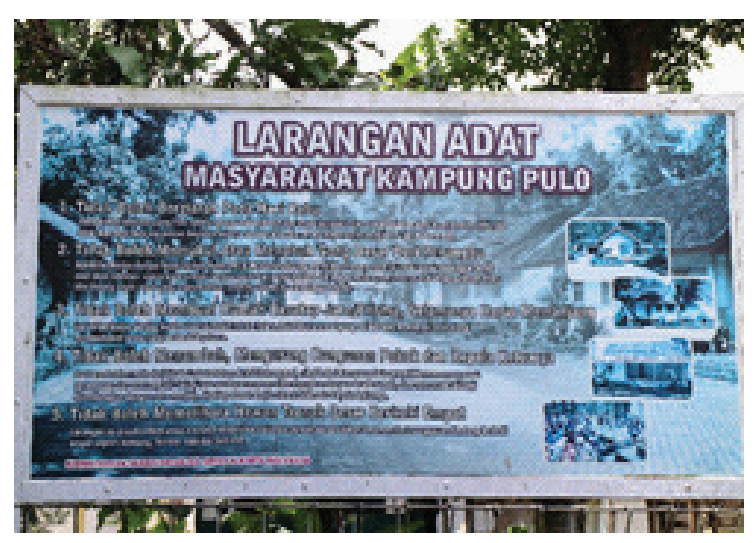

Gambar 3. Larangan Adat Masyarakat Kampung Pulo (Sumber: Sriwardani, 2019)

4. Larangan membangun rumah dengan atap berbentuk prisma. Hal ini berkaitan dengan kejadian tragis yang menimpa satu-satunya anak lelaki Embah Dalem Arief Muhammad, sebagaimana dikisahkan secara turun temurun oleh pemangku adat. Tatkala anak lelaki semata wayang Embah Dalem Arief Muhammad cukup umur untuk dikhitan, maka dilaksanakanlah upacara khitanan dengan mengarak "raden nganten" dalam sebuah tandu berbentuk prisma. Pada saat diarak, tiba-tiba datang angin kencang yang membuat arak-arakan kocar-kacir dan mencelakakan "raden nganten" hingga meninggal dunia. Untuk memperingati kejadian tersebut, maka Desa Adat Kampung Pulo pamali (dilarang) membuat atap berbentuk prisma.

5. Larangan memukul gong besar. Ini masih berkenaan dengan kejadian pamali nomor 4, yakni sebuah kejadian tragis yang menimpa arak-arakan "raden nganten" dan dalam kejadian itu gong besar merupakan alat musik dalam gamelan pengiring. Jadi untuk memperingati kejadian itu, desa adat Kampung Pulo pamali membunyikan gong besar.

Larangan tersebut tertulis dan tercantum di kawasan ini sehingga bisa diketahui jelas oleh para pengunjung (lihat gambar 3). Larangan adat di Kampung Pulo ini terbentuk dari kejadian dan kepercayaan secara turun temurun. Walaupun tidak 
tertulis adanya hukuman atau sanksi jika melanggar larangan tersebut, namun masyarakat Kampung Pulo dan masyarakat di luar kampung Pulo tetap mentaati larangan tersebut. Menurut Juju (2014: 168), kata larangan dapat juga diartikan sebagai pantangan, begitu juga istilah tabu dapat diartikan sebagai larangan atau yang dilarang. Jika melanggar tabu maka pelanggar akan terkena bencana/malapetaka. Sedangkan yang melanggar pantangan akan terkena sanksi fisik atau sanksi sosial. Beberapa cerita narasumber mengatakan, jika ada pengunjung atau masyarakat sekitar yang melanggar larangan adat akan diberi peringatan, namun jika tetap diabaikan biasanya akan terjadi suatu kejadian yang tak diharapkan.

\section{Karakteristik Bentuk Rumah Adat Kampung Pulo}

Rumah di Pemukiman Kampung Adat Pulo

Komplek rumah Kampung Pulo terdiri dari 6 rumah dan 1 musola. Menurut Fauziah (2017: 43-44), susunan rumah kampung ini berbentuk $U$, yaitu 3 pasang rumah saling berhadapan atau simetris yang di antaranya terdapat lapangan di bagian tengahnya dan satu musola di bagian barat pemukiman (terlihat pada gambar 2 komplek rumah adat dan gambar 4 sketsa block plan). Komplek rumah dan mushola yang saling berhadapan, yaitu muka bangunan mengarah terpusat ke tengah. Menurut Suwardi (2011: 106), bentuk tersebut mencerminkan konsep kebersamaan berkumpul (ngariung) yang menunjukkan sistem kekerabatan yang erat. Hal ini juga didukung dengan kenyataan bahwa penghuni rumah merupakan satu keturunan leluhur yang sama, terutama berdasarkan dari pihak perempuan.

Bentuk dasar rumah adalah jolopang, yaitu bentuk memanjang/persegi panjang, berupa rumah panggung, dengan arah rumah menghadap utara atau selatan. Lapangan berfungsi untuk dilaksanakannya

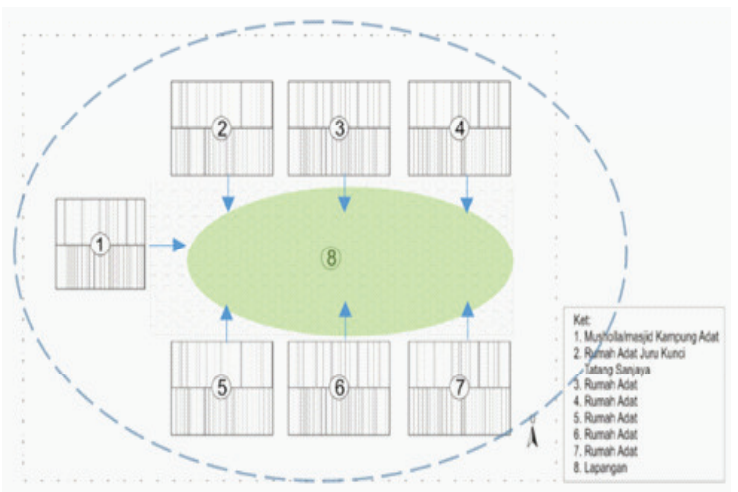

Gambar 4. Sketsa Block Plan - pola pemukiman Kampung Pulo

(Sumber: Sketsa Sriwardani, 2019)

berbagai aktivitas warga, terutama kegiatan upacara adat. Lokasinya berdekatan dengan pintu masuk kampung dan langsung sebagai akses wisatawan melewati kampung adat. Di lapangan ini biasanya wisatawan berswafoto mengabadikan rumah adat Kampung Pulo. Ada beberapa kegiatan upacara adat yang boleh disaksikan oleh masyarakat umum, didukung oleh dinas pariwisata sehingga seringkali upacara adat mengundang keramaian dari warga diluar Kampung Pulo.

Berdasarkan gambar 4, diperlihatkan susunan bangunan yang terdapat di Kampung Pulo yang terdiri dari enam rumah adat dan satu musola. Pada dasarnya, keenam rumah tersebut memiliki bentuk yang sama.Namun 5 rumah sudah mengalami perombakan dengan menambah luasan ruang dengan menggeser posisi dinding lebih ke depan, terutama pada bagian tepas yang lebih sempit dari pada rumah adat asli, serta beberapa material bangunan yang sudah berubah dari aslinya, seperti terlihat pada penutup atap berbahan genting dan bentuk atap berupa undakan pelana. Selain itu, fasade atau tampak bangunan yang memiliki kusen dan jalusi jendela yang berbeda dari rumah asli. Rumah juga diberi warna selain warna putih (rumah no. 5). Hanya satu rumah yang masih terjaga keasliannya baik dari bentuk tata ruangnya maupun material/bahan bangunan (rumah 


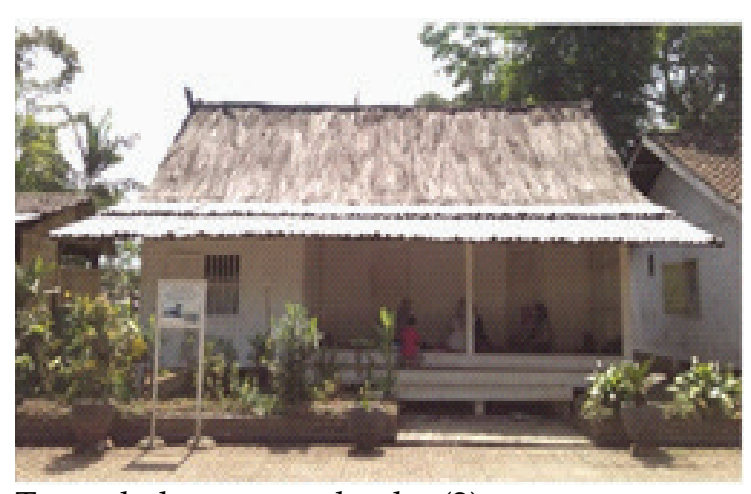

Tampak depan rumah adat (2)

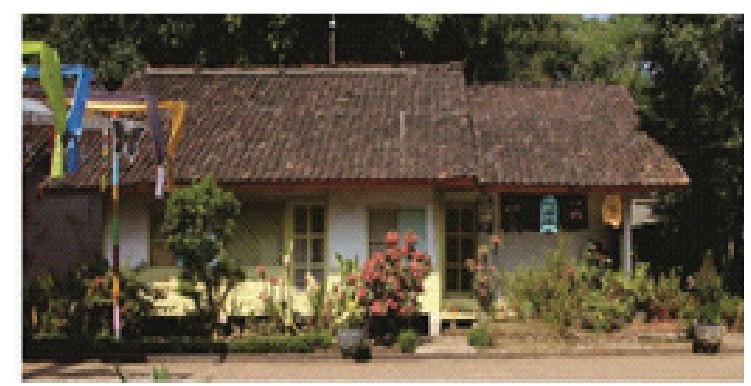

Tampak depan rumah adat (5)

Gambar 5. Tampak depan rumah adat (mengacu dari sketsa site plan pada gambar 3) (Sumber: Sriwardani, 2019)

no. 2, terlihat pada gambar 5). Rumah tersebut ditempati oleh juru kunci.

Pada dasarnya rumah-rumah tersebut diperbolehkan menambah luasan rumahnya, hanya saja harus dimusyawarahkan terlebih dahulu. Meningkatnya kebutuhan ruang menjadikan beberapa rumah mengalami perombakan perubahan tatanan ruang.

\section{Sirkulasi Udara Rumah Adat Kampung Pulo}

Rumah 2 adalah rumah adat dengan bentuk asli (lihat gambar 5). Rumah adat Kampung Pulo hampir sama dengan rumah adat Sunda lainnya, yaitu berupa panggung atau kolong. Pembangunan rumah ini tidak merusak tanah dikarenakan struktur tidak tertanam di dalam tanah, melainkan tiang kayu rumah diletakkan di atas kayu/ batu/ semen. Hal ini menjadikan lantai rumah tidak lembab karena tidak langsung bersentuhan dengan tanah. Sirkulasi udara di bagian kolong rumah memberikan kesejukan ke bagian dalam rumah melalui

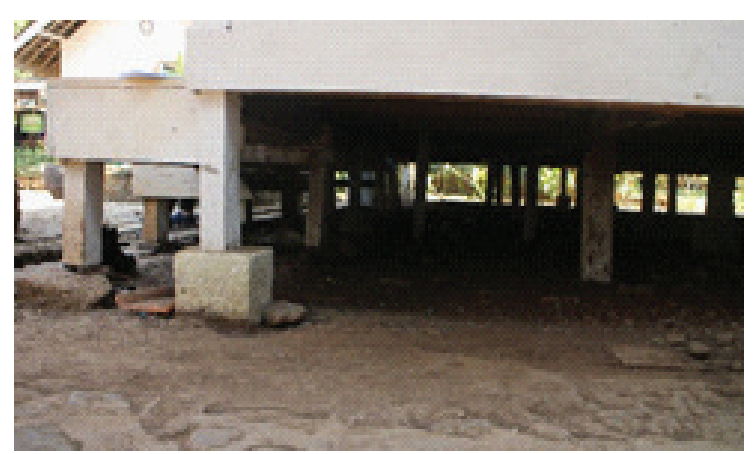

Gambar 6. Pondasi dan struktur rumah panggung Kampung Pulo

(Sumber: Sriwardani , 2019)

celah-celah penutup lantai yang berbahan bambu. Kolong rumah dikondisikan bersih tanpa ada simpanan barang di bawahnya. Tanah tumpuan bangunan juga merupakan tanah keras yang datar, sehingga tumpuan berdiri tegak dan sejajar rata.

Sirkulasi udara merupakan pertukaran udara dari luar maupun dari dalam rumah. Udara bergerak berganti dari luar ke dalam maupun sebaliknya. Pertukaran udara yang baik memberikan kenyamanan penghuninya disebabkan memberikan kesegaran dan kenyamanan pengaturan suhu udara, serta mengatur kelembaban di dalam rumah. Hal ini dapat dilakukan salah satunya dengan menyediakan ventilasi. Keadaan rumah adat Kampung Pulo ini memberikan ruang gerak udara dengan cukup luas, yaitu tidak hanya dari ventilasi utama berupa jendela atau pintu saja namun seluruh bahan bangunan yang terbuat dari bambu memberi celah sehingga udara dapat masuk dan keluar dari berbagai arah. Seperti kolong rumah mengalirkan udara dibawah rumah yang juga mengalir dari celah-celah lantai palupuh sehingga keadaan rumah tetap kering dan sejuk. Begitu juga dari dinding yang terbuat dari bilik/anyaman bambu, anyaman bersilangan menghasilkan celah kecil untuk lewatnya udara. Bentuk panggung juga berfungsi menjaga ketahanan material bangunan rumah yang berbahan bambu dan kayu. Bambu dan kayu 


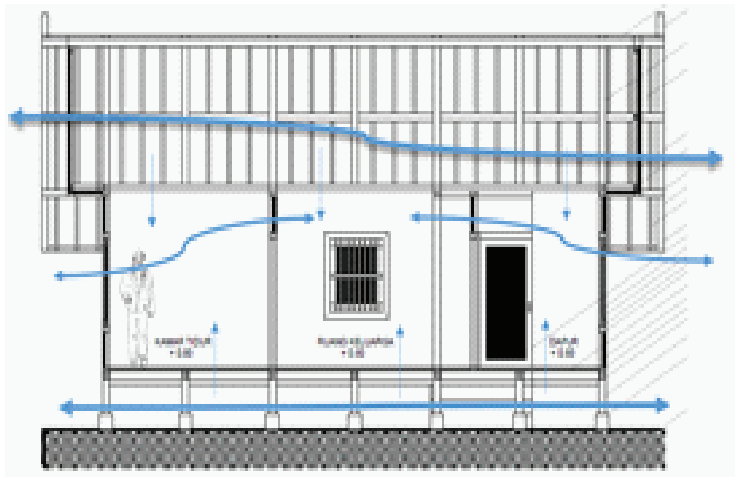

Gambar 7. Potongan memanjang: Ilustrasi sirkulasi udara rumah adat Kampung Pulo (Sumber: Sketsa Sriwardani, 2019)

sangat rentan terhadap air dan lembab, dengan dibuat berjarak atau panggung sekitar $40 \mathrm{~cm}-60 \mathrm{~cm}$ maka menjaga material bangunan tetap kering. Ghifari (2014: 27-28) menjelaskan bahwa sebaiknya material bambu tidak langsung bersentuhan dengan tanah. Hal ini dikarenakan air dapat masuk ke dalam serat yang mengakibatkan lembab dan munculnya jamur. Akibat dari rusaknya material karena lembab dan berjamur dapat mengurangi/menghilangnya kekuatan material tersebut.

Jendela rumah adat berbentuk empat persegi panjang dengan jalosi kayu dan daun jendela tertutup anyaman rotan. Daun pintu rumah juga tertutup anyaman rotan di tengah rangkanya. Keseluruhan bagian rumah menggunakan material yang memiliki celah-celah kecil dari anyaman sehingga sirkulasi udara dapat masuk dan keluar dengan baik, walaupun pintu dan jendela tertutup rapat.

\section{Struktur dan Material Rumah Adat Kampung Pulo}

Bentuk atap rumah adat adalah suhunan jolopang (jolopang yaitu tidur tekungkap, dan atau jelepeng yaitu tidur telentang) dan suhunan julang ngapak (burung julang mengepak sayap). Bentuk atap tersebut, menurut Suwardi (2011: 105), menunjukkan kesederhanaan, baik dalam bentuk, gaya, maupun teknik pembuatannya. Selain itu, hasil penglihatan di lapangan dan data

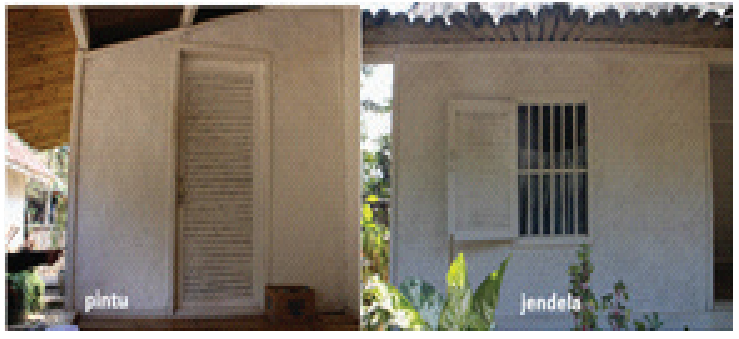

Gambar 8. Bentuk pintu dan jendela sebagai ventilasi udara alami (Sumber: Sriwardani, 2019)

Suwardi (2011: 106-107), bahwa rumah asli (tampak muka rumah 2) dengan bagian inti dari rumah beratapkan ijuk dan area publik berupa teras dan ruang tamu beratapkan talahab (bilahan bambu yang dibagi dua disusun bersilangan). Pada bagian ujung atap terdapat capit hurang (cagak gunting) karena bagian ujung ini berbentuk seperti cagak atau tanduk munding yang terbuat dari kayu dan dililit dengan ijuk. Fungsi dari bentuk ini adalah untuk menghindari kebocoran saat hujan serta untuk menolak pengaruh negatif (Suwardi, 2011: 105).

Bangunan rumah adat yang masih asli memiliki struktur bangunan berupa tiang berbahan kayu yang diletakkan di atas kayu/semen (lihat gambar 6), dinding terbuat dari anyaman bambu/bilik yang dicat warna putih dan lantai terbuat dari palupuh, yaitu bambu yang dibentuk lempengan bambu digelarkan di atas rangka bambu. Sambungan di beberapa bagian struktur menggunakan paku. Terdapat 5 pintu dan 5 jendela, dengan kusen serta daun pintu jendela yang terbuat dari material kayu.

Struktur bangunan dengan tiang kayu yang diletakkan di atas semen/batu yang berfungsi sebagai pondasi membuat bangunan lebih fleksibel bergerak dan bergeser jika terjadi guncangan. Hal ini disebabkan kayu memiliki daya lentur lebih baik dibandingkan material beton (Lestari, 2018). Menurut Nuryanto dkk. (2015: 3), penggunaan material bangunan tradisional Sunda telah memenuhi persyaratan bangunan tahan gempa, disebabkan penggu- 


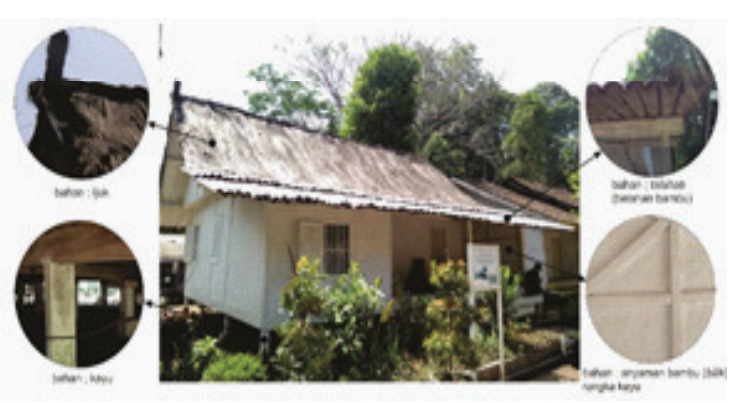

Gambar 9. Bahan/material bangunan rumah adat Kampung Pulo (Sumber: Sriwardani, 2019)

naan kayu dan bambu yang sifatnya lebih ringan. Kayu dapat sebagai struktur yang baik karena kemampuannya menahan kompresi dan memiliki kadar air rendah. Sedangkan bambu memiliki sifat mekanik seperti kayu dan bahan yang cepat terbarukan dikarenakan sumber bambu banyak tersedia.

Bahan dan bentuk denah rumah adat Kampung Pulo masuk kepada kategori standar perencanaan ketahanan gempa. Mengikuti pendapat Nuryanto dkk. (2015: 1), batasan perencanaan tersebut dari kategori SNI yang sesuai dengan bentuk Kampung Pulo, adalah a) denah bangunan rumah adat Kampung Pulo simetris, sederhana dan tidak terlalu panjang, b) konstruksi atap menggunakan bahan ringan dan sederhana, yaitu berbahan ijuk dengan rangka kuda-kuda dari kayu, c) tanah dasar pondasi merupakan tanah kering, padat dan merata kekerasannya dan lahan di Kampung Pulo ini memiliki tanah yang datar dan keras (lihat gambar 6), d) adanya balok pondasi yang mengikat pondasi satu dengan yang lainnya, e) rumah memiliki kolong/panggung dengan jarak tanah ke lantai 40-60 cm. Menurut Triyadi (2008:132133), gubahan struktur bangunan (termasuk rumah adat Kampung Pulo) sangat solid dan kaku, membentuk satu kesatuan yang utuh sehingga dapat mengantisipasi beban gempa.

Hal ini diuraikan oleh Triyadi (2008: 134), bahwa rangka struktur bangunan

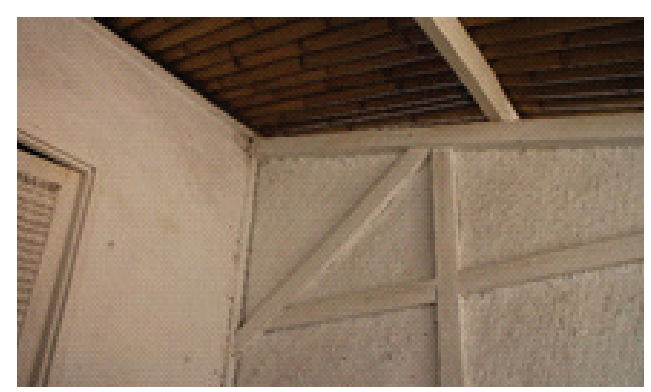

Gambar 10. Rangka bangunan rumah adat Kampung Pulo

(Sumber: Sriwardani , 2019)

menggunakan kayu, yaitu pada kolom, balok, rangka kuda-kuda atap, dan lainnya. Dengan bentuk bangunan persegi panjang, setiap kolom diikat oleh balok untuk menyatukannya. Bangunan juga semakin kaku dengan rangka dinding yang teratur dan dikaitkan dengan kolom, di mana rangka ini berfungsi untuk menempel pada anyaman bambu. Sehingga rumah adat Kampung Pulo ini dapat menjadi suatu hunian yang teruji ketahanannya terhadap gempa, karena susunan struktur dan pemilihan material bangunan yang ringan.

Dinding bangunan rumah adat Kampung Pulo menggunakan bilik/ anyaman bambu. Bilik ini ditempel pada rangka tiang yang terhubung dengan kolom. Rangka dinding tidak hanya untuk menyangga dinding bilik tetapi juga sebagai rangka pintu dan jendela. Sambungan antara tiang dan rangka bisa menggunakan pen atau pasak, dan juga saat ini sudah menggunakan paku pada beberapa titik. Dinding bilik dan rangka bangunan diberi cat berwarna putih, dengan alasan agar terlihat lebih rapi (lihat gambar 10). Alasan ini dilatarbelakangi bahwa sebelum listrik ada pencahayaan menggunakan lampu minyak dan efeknya adalah dinding bilik menjadi hitam akibat asap dari lampu minyak tersebut.

Pada lantai bangunan, rangka balok utama berbahan kayu sedangkan rangka lantai menggunakan bambu dengan penutup lantai berupa palupuh. 


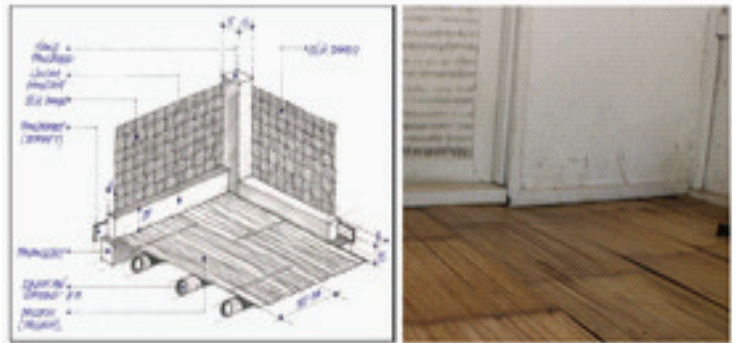

Gambar 11. Lantai bangunan rumah berbahan bambu palupuh

(Sumber: Gambar kiri, Nuryanto dkk, 2015. Kanan: Sriwardani , 2019)

Menurut Nuryanto dkk. (2006: 5), palupuh adalah penutup lantai yang terbuat dari bambu yang dirajam atau dipipihkan. Luas palupuh disesuaikan berdasar kebutuhan dan luas ruang. Bambu untuk palupuh biasanya merupakan bambu gombong berdiameter $\pm 15-20 \mathrm{~cm}$, dan tebal $\pm 12-15 \mathrm{~mm}$, sehingga saat diproses dengan dibelah dan dirajam/dipipihkan, maka lebarnya bisa mencapai $\pm 30 \mathrm{~cm}$. Lantai palupuh ini menjadikan beban lantai lebih ringan, sehingga rangka tumpuan berupa bambu dapat kuat menopang bidang lantai.

Secara keseluruhan penggunaan material dan teknik bangunan rumah adat Kampung Pulo menghasilkan beban rumah yang lebih ringan dan kuat. Beban yang ringan dan kuat tersebut menjadikan rumah adat ini lebih tahan terhadap guncangan dan aman bagi penghuni di dalamnya.

Ukuran dan Ruang Rumah Adat Kampung Pulo

Rumah Adat Kampung Pulo merupakan hunian rumah yang memiliki ruangruang pokok untuk memenuhi kebutuhan penghuninya. Penghuni yang terdiri dari satu keluarga, yaitu ayah, ibu dan anak, membentuk ruang kamar, ruang keluarga, dan dapur serta goah.

Rumah Adat Kampung Pulo berukuran $8.50 \mathrm{~m} \times 7.50 \mathrm{~m}$, dengan pembagian ruang rumah adat sebagai berikut:

- Tepas (teras/serambi muka) dengan ukuran $5.67 \mathrm{~m} \times 2.50 \mathrm{~m}$ yang berfungsi sebagai penerima tamu dan berbagai kegiatan bersifat publik,

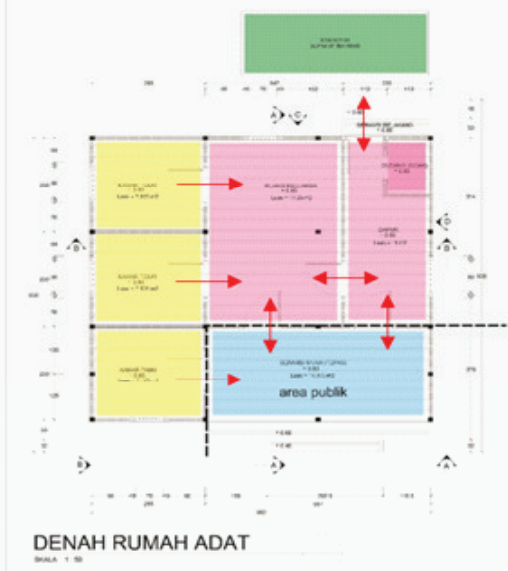

Gambar 12. Denah rumah adat Kampung Pulo dan garis hubungan ruang (Sumber: Sketsa Sriwardani, 2019)

- Ruang keluarga berukuran $3.47 \mathrm{~m} \times 5 \mathrm{~m}$,

- Duakamartidurberukuran $2.83 \mathrm{~m} \times 2.5 \mathrm{~m}$,

- Satukamar tamu berukuran $283 \mathrm{~m} \times 25 \mathrm{~m}$,

- Goah (gudang) yang berada di dapur,

- Hawu (tungku perapian) berukuran $1.2 \mathrm{~m} \times 1.6 \mathrm{~m}$. Ruang ini berfungsi sebagai tempat untuk memasak. Peralatan dapur juga disimpan di area ini.

Tinggi plafon rumah $2.50 \mathrm{~m}$. (data lapangan dan Suwardi, 2011: 104). Sedangkan untuk area khusus, seperti jamban dan kandang diletakkan terpisah dari rumah utama yang berada di bagian belakang rumah.

Ilustrasi gambar yang diperlihatkan pada lokasi wisata tidak dapat dijadikan acuan karena bentuk denah yang tidak sesuai dengan ukuran aslinya. Oleh karenanya, hasil pengukuran di lapangan dapat diperlihatkan berupa gambar kerja (Denah, Tampak dan Potongan) seperti tampak pada gambar 12 dan 13). Grid atau jarak antar kolom bangunan adalah $+2,5 \mathrm{~m}$. Jarak kolom ini juga menjadikan batasan dan luas antar tiap area ruang.

Pengelompokan ruang di rumah adat ini berdasarkan jenis kegiatan dan hubungan antar ruang (gambar 12). Ruang kamar dikelompokkan di sisi barat bangunan. Terlihat pada garis panah (di gambar 12), kamar tamu tidak terhubung dengan ruang keluarga namun berhubungan dengan 


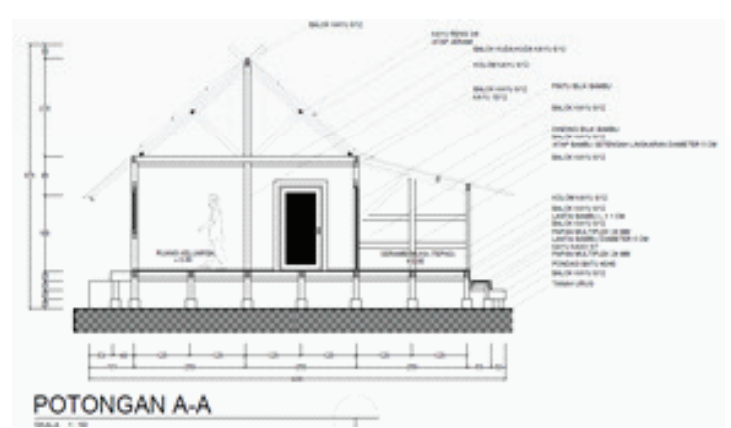

Gambar 13. Potongan rumah adat Kp. Pulo (Sumber: Sriwardani, 2019)

tepas (teras) melalui akses pintu, sehingga tamu yang menginap tidak mengganggu privasi keluarga.

Akses pintu utama untuk masuk ke dalam rumah utama melalui pintu yang berada di bagian tengah tepas sehingga tamu sebelum memasuki area privat diterima dahulu di tepas/teras. Akses pintu ke dalam rumah juga dapat melewati pintu dapur di bagian depan rumah. Kamar tidur keluarga di dalam rumah berhubungan dengan ruang keluarga. Dapur berhubungan dekat dengan ruang keluarga dan tepas. Hal ini juga sebagaimana dapur yang berfungsi sebagai tempat mempersiapkan makanan atau jamuan yang diperuntukkan untuk keluarga maupun untuk tamu. Akses dapur dapat dikatakan sebagai area semi publik karena ia memiliki jalur tersendiri tanpa melewati area privasi. Di Kampung Pulo sudah tidak ada bangunan leuit (lumbung padi). Penyimpanan bahan makanan langsung disimpan di dapur dan juga goah/gudang. Untuk area jamban/toilet dan sumur diletakkan berjauhan/tidak berhubungan langsung dengan area rumah. Jamban merupakan area terbuka sehingga dapat di akses oleh siapa saja, namun tetap berada di area pekarangan rumah. Tamu dapat menuju jamban tanpa perlu memasuki area dalam rumah. Jamban tidak disatukan de-ngan area rumah karena area ini merupakan area basah dan najis, sedangkan rumah dianggap suci dimana ritual dan kehidupan berkeluarga dilaksanakan di rumah dan dianggap sebagai tempat yang suci.

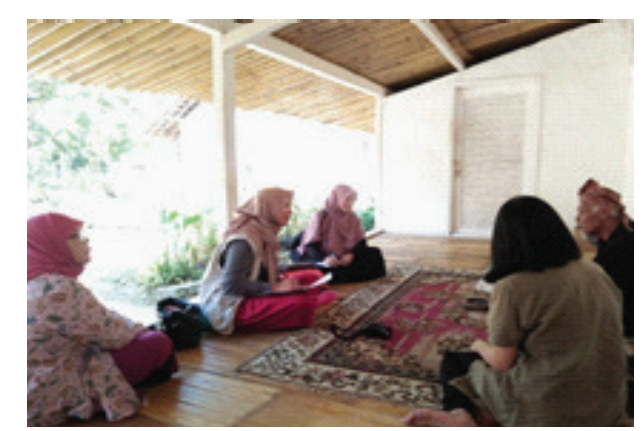

Gambar 14. Area Tepas untuk menerima tamu (Sumber: Sriwardani, 2019)

Kebutuhan peralatan di rumah adat sudah terakses dengan listrik, sehingga barang elektronik boleh dipergunakan. Masyarakat di Kampung Pulo tidak menolak adanya perkembangan jaman, namun tetap masih menghormati tradisi dan beberapa ketentuan apa yang boleh dan tidak dikerjakan.

Sepanjang peneliti mencari berbagai sumber literatur dan data di lapangan, belum ada dokumentasi yang memperlihatkan keadaan ruang dalam rumah adat.

Saat penelitian di lapangan, tamu hanya dipersilahkan di bagian teras saja, dan tidak diperkenankan memasuki rumah, karena anak dari kuncen sedang sakit. Namun, kuncen mempersilakan peneliti untuk mengukur dan mendokumentasikan di bagian luar rumah. Struktur pembagian rumah dapat terlihat dari struktur bangunan yang memperlihatkan modul ruang di dalam rumah.

Jarak antar tiap bangunan/tetangga 2.82 $\mathrm{m}$, sehingga bangunan tidak berhimpitan. Jarak rumah tersebut memungkinkan untuk tiap rumah memiliki bukaan seperti/jendela di tiap sisinya. Seperti pada gambar 16, di sisi bersebelahan terdapat jendela. Dengan jarak tersebut juga, dinding rumah tidak tempias oleh hujan sehingga keadaan rumah seperti dinding dan kayu bangunan lebih awet.

Area pendukung seperti jamban, sumur, dan kandang binatang berkaki dua terletak di belakang rumah, terpisah dari area rumah. Hal ini dimaksudkan agar area rumah tetap bersih, kering dan suci serta tidak tercampur najis atau dengan area basah. 


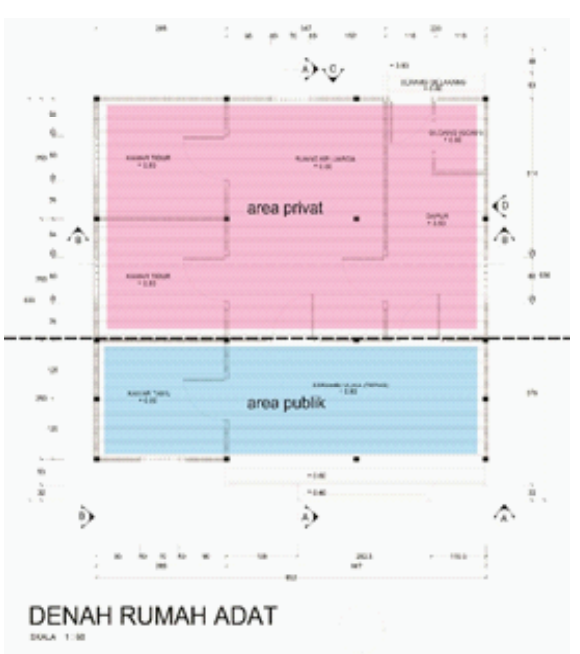

Gambar 15. Denah pembagian area privat-publik di rumah adat Kampung Pulo (Sumber: Sketsa Sriwardani, 2019)

Rumah dianggap sebagai area yang baik dan bersih. Rumah tidak hanya sekedar sebagai tempat tinggal tetapi juga dianggap sebagai tempat yang suci (sakral) (Suwardi, 2011: 104). Oleh karena area rumah yang suci dibuat terpisah dengan area service/basah (jamban, sumur dan kandang).

Dari bahasan tersebut di atas tiap bagian/bentuk bangunan dapat dikelompokkan untuk memperjelas karakteristik rumah adat yang bisa dijadikan sebagai konsep suatu hunian masa kini.

1. Komplek/lingkungan perumahan.

- 6 Rumah dan 1 musola/masjid

- Komplek perumahan melingkar berbentuk U.

Latar Belakang: Adanya larangan adat, yaitu larangan menambah atau mengurangi jumlah rumah.

Konsep: kebersamaan, berkumpul (ngariung)

Makna: membentuk sistem kekerabatan sebagai satu keturunan yang sama.

Fungsi: Menjaga eksistensi bangunan tradisional Kampung Adat Pulo, dan menjaga kepadatan pertumbuhan hunian sehingga tetap selaras dengan alam.

- Tidak memelihara hewan ternak.

Latar Belakang: Adanya larangan adat yaitu tidak boleh memelihara hewan berkaki empat kecuali kucing.

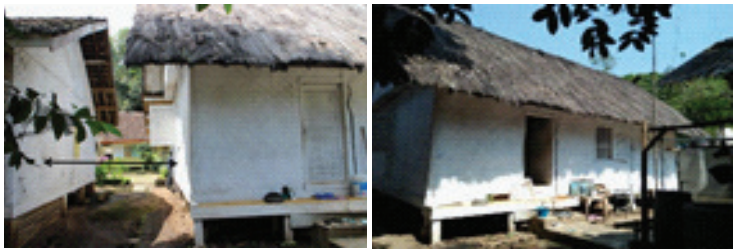

Gambar 16. Tampak bagian belakang rumah adat (Sumber: Sriwardani, 2019)

Fungsi: menjadikan kampung tetap terjaga kebersihan dan menciptakan lingkungan yang sehat.

- Orientasi muka bangunan menghadap Utara dan Selatan/ membujur timur ke Barat. Tiap rumah memiliki jarak.

Konsep: Pola terbit tenggelam matahari.

Fungsi: Setiap bagian sisi rumah mendapatkan cahaya dan udara dengan baik, sehingga memungkinkan setiap sisi rumah memiliki jendela/pintu sebagai ventilasi udara dan cahaya.

2. Penghuni Rumah Adat

- Satu rumah adalah $1 \mathrm{KK}$.

- Penghuni rumah 4-5 orang.

Latar Belakang: Aturan adat bahwa jumlah penduduk 23-26 orang. Penerus rumah berdasarkan garis keturunan perempuan tertua, dan anak yang menikah keluar rumah. Ada pergantian jika orang tuanya meninggal.

Konsep: Hubungan Sosial

Makna: Rumah sebagai interaksi antara orang tua dan anaknya, tempat mendidik budaya dan moral.

Fungsi: Menjadikan hunian lebih nyaman, terhindar dari kepadatan penduduk dan terjaga privasi setiap anggota keluarga, namun tetap memiliki hubungan kebersamaan yang erat.

3. Rumah Adat Kampung Pulo

- Rumah panggung.

Konsep: lantai tidak langsung bersentuhan dengan tanah. Bangunan kaku dan kuat.

Fungsi: menjadikan rumah tidak lembab dan sejuk. Sirkulasi udara mengalir dari bagian bawah lantai. struktur konstruksinya menjadikan rumah panggung 
menjadi hunian yang aman karena tahan terhadap guncangan seperti gempa.

- Material bangunan dari bahan alami seperti kayu, bambu dan ijuk pada penutup atap.

Konsep: menyatu dengan alam.

Fungsi:1) membuat rumah memiliki beban lebih ringan dan kuat. Sirkulasi udara dalam rumah dapat mengalir dengan baik dari celah-celah bilik (dinding anyaman bambu), atap dan palupuh (penutup lantai berbahan bambu), 2) memunculkan material alami sebagai bahan bangunan tersebut berguna menjaga kondisi suhu thermal alami tanpa menggunakan udara buatan yang menggunakan daya listrik berlebihan.

- Bentuk atap rumah berupa suhunan jolopang (susunan membujur atau tergolek lurus) atau lebih kita kenal dengan bentuk atap pelana.

Latar Belakang: Larangan adat untuk tidak membuat atap berbentuk prisma.

Fungsi: Atap ini mampu menghindari kebocoran dan mengalirkan arah air hujan ke bagian depan dan belakang rumah, sehingga tidak merusak bagian tetangga rumah. Selain itu, aliran udara dapat masuk dari sisi barat dan timur masuk di dalam atap dan memberi kesejukan di bagian dalam rumah.

4. Luas hunian rumah adat adalah

- $63.75 \mathrm{~m} 2$, luas tanpa area tepas/teras adalah $49.575 \mathrm{~m} 2$. Jika dibagi maksimal penghuni 5 orang, maka luas minimal per orang untuk rumah adat ini adalah kurang lebih $9.92 \mathrm{~m} 2$.

Konsep: Kesederhanaan

Fungsi: Sebagai hunian yang memiliki ruang gerak sesuai kebutuhan dasar gerak manusia.

\section{Ruang Aktifitas}

- Tepas (teras): Kegiatan upacara adat dan menerima tamu dilakukan di tepas. Ia dianggap sebagai ruang tamu.

Fungsi: Tamu tidak dapat melihat bagian dalam rumah. Area publik dan privat terpisah dengan jelas, sehingga kenyamanan penghuni rumah tetap terjaga.

- Ruang dalam terdiri dari ruang keluarga dan ruang tidur, yaitu sebagai tempat aktivitas penghuni rumah.

Fungsi: Sebagai area privat

- Goah (gudang) yang berada di dapur serta hawu (tungku perapian).

Fungsi: sebagai tempat untuk memasak dan menyimpan peralatan dapur.

6. Area Pendukung

- Sumur, jamban, dan kandang hewan berkaki dua, seperti ayam, diletakkan terpisah dari area rumah.

Konsep: Menjaga area suci (sakral)

Fungsi: Menjaga kebersihan dan kesucian rumah.

\section{SIMPULAN}

Karakteristik rumah adat terbentuk dari perjalanan sejarah Kampung Pulo itu sendiri. Beberapa hal dilatarbelakangi oleh adanya aturan dan larangan atau pantangan adat yang asal usulnya pun berdasarkan pengalaman sejarah kampung adat Pulo, sehingga pemukiman kampung adat tetap terjaga kenyamanannya. Kelestarian terjaga dengan adanya aturan, konsep dan larangan adat, seperti ketentuan jumlah bangunan, bentuk bangunan, ketentuan memelihara hewan dan lainnya. Hasilnya terlihat dengan area pemukiman yang bersih dan nyaman. Rumah Kampung Pulo tidak hanya sebagai tempat berteduh namun karakteristik tata ruangnya yang berdekatan menjadikan rumah sebagai hunian yang mengedepankan interaksi harmonisasi dan menciptakan hubungan sosial antar keluarga. Sebagai suatu kawasan pemukiman, kampung Pulo menunjukkan hubungan kekerabatan yang erat melalui tatanan pola susunan rumah-rumah dan masjid/musola.

Karakteristik tersebut di atas dapat menjadi acuan atau konsep dalam perancangan hunian masa kini yang sehat dan alami. Selain itu, menciptakan ruang gerak 
yang tidak berlebih-lebihan, namun tidak juga membatasi, melainkan selaras, berinteraksi dan menghormati alam dalam menciptakan suatu hunian.

\section{Ucapan Terima Kasih}

Penelitian ini didanai oleh DIPA ISBI Bandung. Ucapan terima kasih dihaturkan kepada Rektor ISBI Bandung, dan pihak LP2M ISBI Bandung yang telah memberi kesempatan dalam mewujudkan penelitian ini. Terima kasih juga untuk para narasumber dan dari berbagai pihak sehingga terwujudnya penelitian ini.

\section{Daftar Pustaka}

Alamsyah, S. (2011). Arsitektur Tradisional Rumah Kampung Pulo. Patanjala, 3 (1), 101-118.

Fauziah, S. (2017). Studi Etnografi Komunika si Ritual Adat Masyarakat Kampung Pulo Desa Cangkuang Kecamatan Leles Kabupaten Garut Provinsi Jawa Barat. (Skripsi). Universitas Islam Negeri Syarif Hidayatullah Jakarta.

Ghifari, O. A. (2014). Hasil Hutan Bukan Kayu. Makalah pada Fakultas Kehutanan Universitas Hasanudin Makassar.

Harissman \& Suryanti. (2019). Visualisasi Rumah Gadang dalam Ekspresi Seni Lukis. Panggung, 29 (1), 43-55.

Rochaeni AJ., I. Rachminingsih, \& W. Listiani. (2014). The Cultural Reconstruction Of Taboo Under Mama Uluk's Leadership In Kampong Dukuh, A Sundanese Traditional Hamlet in Garut Regency West Java Indonesia. Panggung, 24 (2), 167-174.

Nuryanto, J. Maknun, \& T. Busono. (2015). Konstruksi Bangunan Tradisional Sunda Ramah Bencana. Departemen Pendidikan Teknik Arsitektur FPTK UPI.
Saringendayanti, E. (2008). Pola Tata Ruang Situs Cangkuang Leles Garut: Kajian Keberlanjutan Budaya Masyarakat Sunda. Makalah pada Jurnal Sastra Dies Natalis ke-50, Fakultas Sastra Universitas Padjajaran,1-30.

Suryo, M.S. (2017). Analisa Kebutuhan Luas Minimal pada Rumah Sederhana Tapak di Indonesia. Jurnal Pemukiman, 12 (2), 116-123.

Triyadi, S. \& A. Harapan. (2008). Kearifan Lokal Rumah Vernakular di Jawa Barat Bagian Selatan dalam Merespon Gempa. Jurnal Sains dan Teknologi EMAS, 18 (2), 123-134.

\section{Webiste/laman:}

Definisi Rumah. Retrieved 18 Agustus, 2019 from http://sni.litbang.pu.go.id/index .php? $\mathrm{r}=$ site/istilah.

KemenPUPR Anggarkan Dana Program Bedah Rumah Sebesar Rp 4,28 Triliunun. Retrieved 18 Agustus, 2019, from https: //tirto.id/kemenpupr-anggarkan-dana -program-bedah-rumah-sebesar-rp 428-triliun-ddsd.

Kejar Target Sejuta Rumah, Pemerintah Dorong Standarisasi Material Bangunan. Retrieved 18 Agustus, 2019 from https: //properti.kompas.com/read/2016/ 03/02/190000421/Kejar.Target.Sejuta. Rumah.Pemerintah.Dorong.Standardisasi.Material.Bangunan.

Lestari, Wita. Rumah Tradisional Indonesia Ternyata Tahan Gempa. Retrieved Agustus 18, 2019 from https://artikel. rumah123.com/rumah-tradisionalindonesia-ternyata-tahan-gempa-47 593\#uD6c8yMj3FHdeZAj.99. 